\title{
Challenges, Roles, and Axiology of Indonesian Digital Literacy During the Pandemic
}

'Putri Tariza Santiula ( Putri.tariza.santiula-2020@fib.unair.ac.id ), 2Adinda Restu Tribhuana ( adinda.restu.tribhuana-2020@fib.unair.ac.id ), ${ }^{3}$ Anastasia Amanda Putri Setiawan ( anastasia.amanda.putri.setiawan-2020@fib.unair.ac.id ), ${ }^{4}$ Adinda salwa ( adinda.salwa-2020@fib.unair.ac.id ),5Moses Glorino Rumambo Pandin ( moses.glorino@fib.unair.ac.id )

Corresponding Author: ${ }^{5}$ Moses Glorino Rumambo Pandin( moses.glorino@fib.unair.ac.id )

${ }^{1234}$ English Literature and Language, Arilangga University, ${ }^{5}$ Departement of English Literature and Language, Airlangga University

admin@fib.unair.ac.id (031) 5035676

\begin{abstract}
Digital literacy is one of the new media, which has a vital role in Indonesian people's lives, especially during the pandemic. In this article, the author will discuss the challenges faced by the community in implementing digital literacy, the role and value of axiology contained in digital literacy during a pandemic. Indonesian society is expected to have good digital literacy skills to balance these urgent needs, especially during a pandemic. This article aims to increase public awareness of the importance of understanding digital literacy. Besides, make efforts to utilize digital literacy to the fullest and realize the challenges faced. This research method uses a combined approach. The results show that digital literacy is critical in various aspects and has axiological value. However, Indonesia still has several challenges implementing digital literacy during the pandemic. Therefore, the government and society are expected to work together to improve the ability and understanding of digital literacy. However, this article still needs to be reviewed further due to the limited data and time available.
\end{abstract}

\section{Keywords: digital literacy, benefits, challenges, axiology}

\section{Introduction}

The world has entered the era of the industrial revolution 4.0, where the times are increasingly advanced. With an increasingly advanced era, this is, of course, followed by increasingly rapid technological developments. Various things can be accessed easily via the internet on digital technology such as smartphones, laptops, computers. This wide-open accessibility must, of course, be directly proportional to the digital literacy capabilities that the community must own. Without these digital literacy skills, people will not easily access things or information on the internet. Digital literacy skills will facilitate the community and function as a filtering tool for the community in responding to all information so that they do not fall into potential negative impacts.

Technological advances that occur today produce advantages that we can take advantage of and produce disadvantages. This deficiency has the potential to impact the freedom to access technology negatively. The shortcomings in question are criminal practices such as online scams, the rapid and widespread spread of misleading information or hoaxes, and other shortcomings. Of course, these things will lead to losses in the community. Moreover, the possibility of this happening will increase with the covid-19 pandemic sweeping the world. 
The COVID-19 pandemic has changed people's lifestyles and habits. It can be proven by using digital media in almost all aspects of life. Currently, in Indonesia, teaching and learning activities and work are carried out from home via electronic devices (laptops, computers, cellphones) and the internet. It is a challenge for the community to sort out information and take advantage of existing digital media to continue carrying out their activities. With these challenges, the Indonesian people are required to improve their digital literacy skills so that they are not trapped in misleading information and consumed by hoax news.

Currently, Indonesia's digital literacy index has not achieved a good score (4.00). However, it is still at a moderate level (3.00), where the information and literacy sub-index scores the lowest compared to other sub-indices (Kominfo.Go.id, 2020). With Indonesia's low score, there needs to be an understanding of digital Literacy's value, role, benefits, and importance, especially during the current pandemic. Of course, this understanding is for the younger generation and people who have entered the productive age of 15-65 years. The productive age group is considered to have a demographic bonus to realize Indonesia's "Golden Generation" vision in 2045.

Indonesia itself has various levels of understanding of digital Literacy. The diversity of levels of understanding makes this issue important and exciting to research. Digital Literacy itself has various meanings according to several sources, but the meaning of each definition is not much different. In defining digital Literacy, we can interpret it by narrowing the definition of 'literacy' and 'digital.' Literacy can be interpreted as a person's ability to read and write. At the same time, digital itself can interpret as a form of technological development related to the internet or computer. In short, digital Literacy can define as the ability to read and write through technological developments such as the internet or computers (Irhandayaningsih, 2020).

Quoted from the book The Role of Digital Literacy in the Pandemic Period (2021) by Devri Suherdi, digital literacy is a person's ability to utilize digital media. A person's ability includes the ability to use and use it wisely according to its use. According to the Ministry of Communication and Information of the Republic of Indonesia, digital literacy can use the computer and extract its information. In addition to the diversity understanding level about the role benefits of digital literacy, the challenges in the digital literacy process become faced by the community will also be the focus of this research.

Based on the background described above, several formulations of the problem can be drawn as follows:

1. What are the benefits of understanding the use of digital literacy?

2. What value schemes are contained in people's perceptions of the importance of digital literacy based on axiology?

3. What are the obstacles faced by the Indonesian people?

\section{Methods}

The type of approach used in this research uses literature and quantitative study methods. Quantitative research is a type of research whose findings can be achieved using statistical or measurement procedures (V. Wiratna Sujarweni, 2014:39). In this study, the authors used a data collection technique in a questionnaire distributed through various digital platforms to collect data from the respondents according to the set targets. The data collected through this questionnaire contains relevant data needed for scientific work activities. The data including; respondents' data, respondents' knowledge of digital literacy, personal opinion regarding the importance of digital literacy, and challenges respondents face when accessing digital literacy activities. The data results collected will then be analyzed using a combined method 


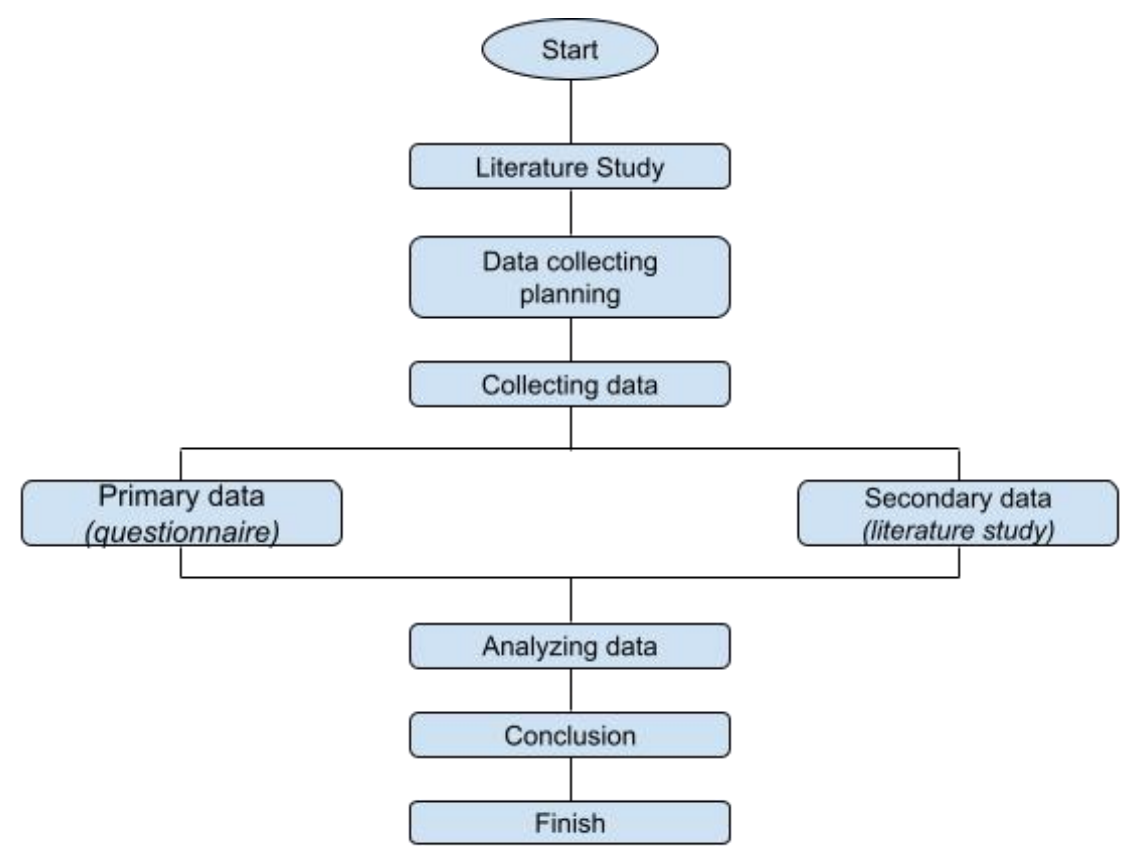

Chart 1. Research Method Flow

\section{The Result of Research}

From the survey results carried out, we have obtained as many as 86 respondents, most of whom are aged $15-25$ years. As many as $98.8 \%$ have understood digital literacy, and many as $1.2 \%$ still do not understand digital literacy. The respondents frequently apply digital literacy in their daily lives, especially to access social media, which is the primary means of communication and interaction with other people during the pandemic.

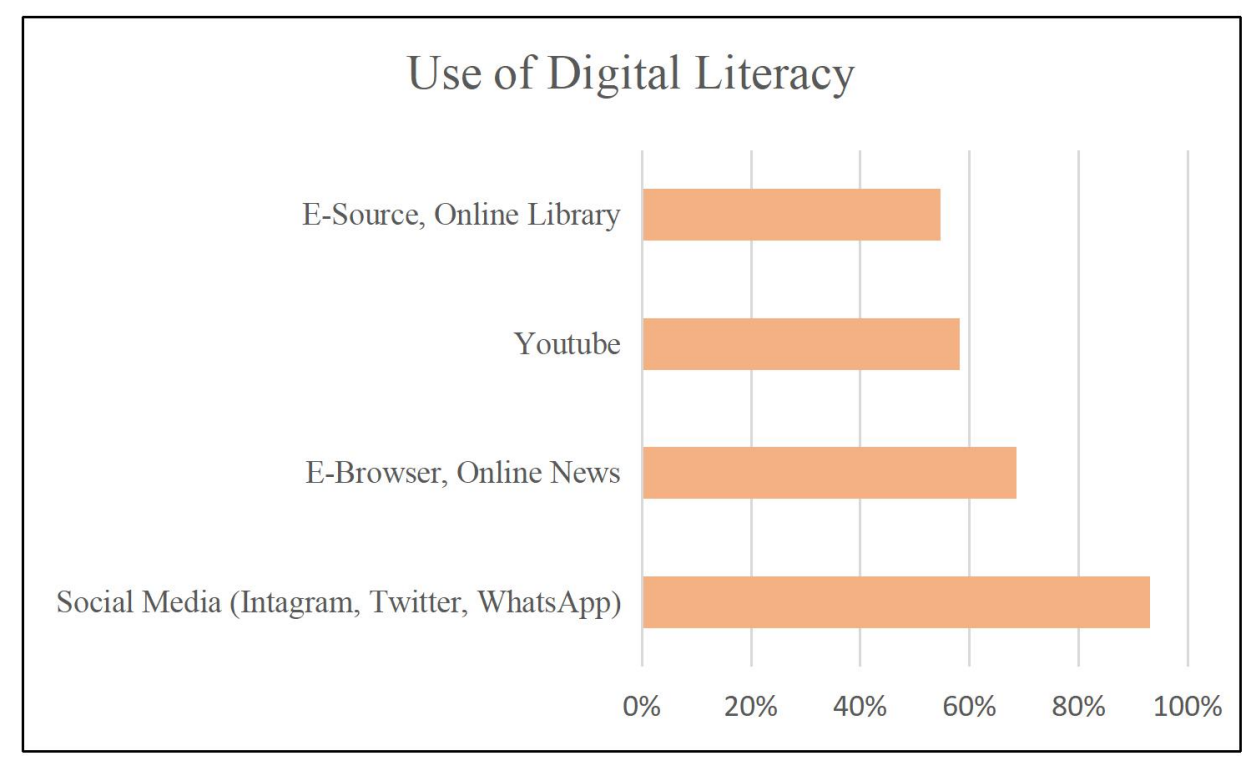

Chart 2. Use of Digital Literacy

Respondents also think that digital literacy during a pandemic is vital. From the survey results, $60.5 \%$ said it was crucial, $32.6 \%$ said it was necessary, and $7 \%$ said it was pretty important. They think it is vital because the times have developed rapidly. However, in Indonesia, internet 
access is still not evenly distributed. Not only that, but they also argue that with digital literacy, they will not readily believe in hoax news and which later can have a negative impact. With the rapid development of technology and the pandemic, they are required to follow these developments so they are not left behind and can still carry out their activities with digital literacy skills.

However, uneven internet access will cause an obstacle. Especially for students and students, internet access is one of the keys to understanding the material from lecturers and teachers. If they do not have a stable internet network, this becomes an obstacle and challenge. Besides network constraints, several things become obstacles for respondents. Such as lack of access, impracticality if someone wants to read journals and articles, websites not available in Indonesia's territory, and constraints on the web server itself.

\section{Discussion}

\section{Role and Benefits}

With the advancement of the era, the more sophisticated the development of existing technology. In responding to this, we are expected to face and live side by side. Mastering technological developments are one way (Khasanah \& Herina, 2019). Technological developments cause communication and information networks to develop - the evidence from the ease of operating digital media, especially in the current digital era.

The digital era has a relationship with digital literacy skills. It is because digital literacy means the ability to read, analyze, and obtain information through various digital sources. The digital era makes it easy for us to find news quickly. In addition to searching, we can also share or disseminate information quickly. This digital literacy encourages a person to be active and critical in analyzing the information obtained (Muslim \& Eid, 2020).

In Indonesia, especially in modern society, digital media is a necessity. It is evidenced when accessing information makes all matters easy and efficient. With this convenience, it is hoped that someone can use it intelligently and wisely (Muslim \& Eid, 2020). We can also see digital media as a necessity during the COVID-19 pandemic. Suddenly, human life has become entirely digital. Face-to-face limitations cause all information and communication to be woven through digital media. Therefore, an understanding and ability in digital literacy are needed.

Digital literacy has an essential role in today's life. Digital literacy acts as the front line in dealing with technological developments. Because digital literacy will make it easier for us to receive and analyze the information we get in this digital era, especially during a pandemic. In addition, digital literacy has a role in finding and disseminating information. Everyone is required to have digital literacy skills because some information can only be accessed through digital media. Therefore, digital literacy has a significant role, especially in living life during this pandemic.

In addition to having a role, digital literacy has various benefits. During this pandemic, digital literacy is helpful in many ways, especially in work and education. Irhandayaningsih (2020) argues that digital literacy skills are needed at the time of entering the pandemic, especially by students due to system changes in learning. Changes in the system outside the network to be in the network mean the learning system has changed to digital. High digital literacy skills will make it easier for students to follow the learning process. For example, students will get convenient and quality learning resources with digital literacy when accessing learning resources. In addition, the teaching and learning process is also carried out through zoom meetings, google meet, google classroom, and many others. 
Digital literacy also has benefits in the field of communication. The ban on face-to-face contact, which was in effect during this pandemic, made most people object, but they were compelled to comply. This prohibition causes us to not meet directly with other people. Therefore, digital literacy is beneficial in terms of communication. We can only communicate through the provided platforms such as WhatsApp, Line, Instagram. With this, we can keep in touch with other people even long distances. In addition, communicating also becomes more efficient with this digital literacy.

The ability and understanding of digital literacy are very much needed today. When all information and communication are sourced from digital media, this is believed that the role and benefits of digital literacy will enable us to face technological developments. In addition, its role and benefits will make our lives easier and more efficient.

\section{Value Scheme of the Importance of Digital Literacy Based on Axiology}

Etymologically, axiology has come from the Greek. The word axion means value, and logos means science. Axiology is a branch of philosophy that focuses on good and evil, right and wrong, and means of ends (Anim, 2021). Axiology is also a science that discusses how humans use their acquired knowledge. According to Hasanah (2020), axiology wants to achieve the essence and benefits of science. Based on the definitions above, it can conclude that axiology is a science that focuses on the nature of the values contained in the knowledge that humans have obtained. Based on axiology, the critical assumption of having digital literacy skills during the COVID-19 pandemic is as follows.

\section{1)Voluntarism}

The value of voluntarism is a value that comes from the will and desires of a person. The term voluntarism comes from the Latin "voluntas," which means desire.

Currently, almost all of our activities can not be separated from the media and digital. Even more so during the Covid-19 pandemic. Therefore, digital literacy is essential to have. Respondents also have an essential opinion regarding digital literacy. They do not want to miss all the information spread through the media and do not want to stutter on the internet and technology. In addition, they also learn digital literacy to increase their knowledge and not to believe the hoax information scattered on social media quickly.

With the pandemic, school activities or work are carried out from home. A lot of media or the web is used as support. These activities can continue to be carried out. The most prominent example is in the education aspect. When we school from home, we use e-learning

as a learning center. It is supported by several other media, such as WhatsApp, Zoom, and Google meet. Suppose we cannot understand how to use or use the media. In that case, we will find it challenging to be able to follow the learning process. Therefore, the respondents desire to understand how to use these media to provide digital literacy.

Besides, a large amount of information is spread on social media, especially during a pandemic. It can be both a benefit and a disaster for readers if they do not have good digital literacy skills. There is a lot of hoax information spread on social media. According to Ananda, Alan, Rani, and Kun (2019), 92.4\% of hoax news spread on social media such as Facebook, Instagram, Twitter, and Path, and $62.8 \%$ spread on WhatsApp, Line, and Telegram. Due to the large number of hoax news being spread, the respondents did not want to believe the news readily. Therefore, they consider digital literacy necessary to prevent hoax news that can later negatively impact. 


\section{2)Pragmatism}

According to Topan (2020), pragmatism is a value that focuses on practical and concrete solutions whose benefits can be felt directly. Having good digital literacy skills will have many positive impacts, such as making it easier to operate media or electronic devices such as laptops, computers, and smartphones. People who understand digital literacy will find it helpful and lighten or speed up their work. That is an example of a practical solution, and its benefits can be felt directly.

Often students are more likely to be required to understand digital literacy. However, since the Covid-19 pandemic, teaches are also asked to be able to have the ability to use learning media to support the success of online learning. However, most Madasrah Ibtodaiyah or Raudhatul Athfal still use WhatsApp group (WAG) media to learn online. As many as $20 \%$ use other media such as zoom meetings, google meet, google classroom, and others (Kholid, 2020). According to Kholid (2020), the limited ability of teachers to operate the media and only take it via Whatsapp is still very far from being able to accommodate ideal online learning. The learning becomes not optimal. Therefore, the benefits of having good digital literacy skills are essential in implementing ideal online learning.

The respondents also consider digital literacy vital because it can hone critical thinking skills. Facione (2013) in Ely, Dian, Elfira (2020) states that critical thinking is self-control in assessing and considering something before making a decision. They are coupled with the global competition requiring people to have good skills and critical thinking. Digital literacy is a means to hone these skills. With high curiosity, people will always ask questions and ultimately seek answers to questions that arise. In this way, critical thinking skills will be honed.

\section{3) Hedonism}

When the COVID-19 pandemic hit, Indonesia held large-scale social restrictions and advised people to stay home. It makes people spend more time at home and less direct social interaction. Along with the large-scale social restriction period, Tiktok became a booming and crowded social media at that time. Many people download the application, especially the younger generation. Tiktok is a social media that allows users to create 15-60 second videos accompanied by a wide selection of features such as music, filters, and several other creative effects (Rahardaya and Irwansyah, 2021).

Not a few people make creative videos to fill their spare time. They make comedy videos, share tips and information, make a point of view (POV) drama, makeup, challenges, and many others. Their videos that appear on other people's homepages or are often called for your page (fyp) can create feelings of pleasure. In addition, many people who like videos also motivate them to make more exciting videos. They can add followers to make them famous creators or so-called TikTok celebrities. Until now, many content creators started their careers from TikTok just because it started from the pleasure of making videos or entertaining others.

On TikTok, there are also many helpful, informative videos. However, it is still possible that videos contain hoax information. However, people quickly respond or correct incorrect information through the comment section or the stitch feature with the rapid spread of information. This stitch feature is a feature that allows users to respond to other users' videos. Because he likes to play Tiktok or make Tiktok videos, he can clarify the hoax information. Therefore, the value of hedonism is a value that starts with pleasure. 


\section{4) Instrumental}

Instrumental value is a value based on its function as a tool. Digital literacy is helpful to facilitate our activities related to technology media. It means that digital literacy is a tool to coexist with increasingly sophisticated technology. According to one of our respondents stated,

I think, Digital literacy in the current era is critical because it will be easier for us to access information with our skills in using technology. With knowledge, we can distinguish between valid information and hoax information.

Digital literacy is a tool to simplify all our activities and can help us be able to sort out valid information and hone critical thinking skills. It is also in line with the responses of our respondents.

With digital literacy, we can find out the latest things that are happening. It is instrumental in the world of lectures like this because it can be used in providing arguments or refutation in discussions and daily life so that they are not easily influenced.

Digital literacy is very important for each individual because it can trigger personal to be more critical and easily understand all forms of information. In addition, digital literacy can also increase self-focus and concentration.

Therefore, digital literacy has the type of instrumental value as a valuable tool for the Indonesian people.

\section{5) Logic}

IIn axiology, there is a criterion to measure the value of something influenced by psychological theory (emotions) and logic (reasonable considerations). Logic is a criterion that measures something valuable or not based on whether or not it is accepted by common sense. In addition, the value of logical criteria is often related to the necessities of life.

Since the pandemic, a new need has emerged. It is due to the cessation of face-to-face activities and must be transferred online, such as schools. Online schools require the primary media closely related to the internet and technology. Therefore, the Indonesian people must have adequate digital literacy skills to continue to carry out their activities. Suppose there are adequate media available but do not have the intelligence to use the media. In that case, it will harm society. Anggraeni, 2019). Therefore, according to Anggraeni (2019), digital literacy is an urgent need for the community, especially students, to continue carrying out all their activities, especially online learning.

Of course, this applies not only to students but also to teachers. If teachers cannot use online learning media, online learning will be hampered, and student learning motivation will decrease drastically. Adnan (2020) in Anim, Armanto, and Sari (2020), most students feel offline learning is more effective and motivating than online learning. Therefore, teachers must also have good digital literacy skills so that online learning can be as effective as offline learning.

Based on this, having digital literacy skills is necessary during a pandemic like this for everyone, not only for the younger generation of students but also for teachers. 


\section{6) Based on Max Scheller's theory}

Max Scheller divides axiology into four categories; material values, vitality values, spiritual values (beauty, justice, truth), and religious values. In the hierarchy of values, religious values are at the top, and material values are at the bottom. Based on this theory, digital literacy is also related to material values and spiritual values (truth).

Material value is a value that involves pleasure and displeasure. The value scheme's material value is almost the same as the hedonistic value derived from pleasure. Interaction on social media for millennials is a pleasure for them. The millennial generation is an Indonesian population born in 1980-2000, and currently, they are in the age range of 19-40 years (Sari,2019). According to Martin (2005) in Sari (2019), The millennial generation is a generation that has high motivation, upholds freedom, is more creative and innovative, and has high competitive power. They also prefer freedom, especially in expressing themselves through social media. The millennial generation's interaction is also very intense. They like to find out about social media looking for information, entertainment, hang out with others through chat or other features available on social media.

While the value of spirituality is a value that is concerned with spiritual values, good and bad, good and evil, and right and wrong. A prominent value in digital literacy is the actual false value (truth) that is the most. We can see this from sorting out accurate and valid information. As previously explained, there is much information circulating on social media, but not all of it is true. During the current pandemic, there is much information about COVID-19 in the media. However, there is also a lot of invalid or hoax information, which is not comforting to the Indonesian people. Therefore, by having digital literacy skills, the truth of the information will be known and can avoid hoax news that can have negative consequences.

\section{Digital Literacy Challenge}

Quoted from the book The Role of Digital Literacy in the Pandemic Period (2021), in simple terms, digital literacy can be interpreted as a person's ability to utilize digital media. In an article entitled 'Unpacking New Media Literacy,' Cen et al. (2011: 85) argues that digital literacy is new media literacy that can be understood into two sets. The first series is from consuming literacy to presuming, and the second series is from functionality to critical literacy. Consuming literacy itself refers to accessing and using media messages at various levels (Rianto, 2019). It is not limited to that understanding alone; consuming literacy can also be expanded into a person's critical skills in processing information. Seeing this change in literacy, the community must be aware of the challenges in digital literacy efforts, especially in the pandemic era, and this point will be explained based on the research that has been done.

It can be seen from the points of the research results. At least about $60.5 \%$ of the community considers digital literacy critical, 32.6\% consider it essential, and 7\% consider it quite important. With this data acquisition, digital literacy becomes quite a crucial thing to be discussed and needs to be understood with precision. The following is the response of one respondent regarding the reasons for the importance of digital literacy.

There are more and more sources for reading. Especially with digitization, we can access reading from anywhere and more efficiently. It is crucial because literacy alone is essential. How do we add insight by reading, which can ultimately help change our worldview, change our bad habits, and many others 
Based on the respondents' statements above, it can be concluded. That digital literacy is critical because it can expand the knowledge that can change a person's perspective and cultivate good habits. However, the current obstacle for Indonesian society is that literacy, especially among students, is still relatively low. It is turned out to be successful in sparking debate. Especially when the World's Most Literate Nations results were released, Central Connecticut State University held the United States in 2017. Showed that Indonesia was in the 60th position out of 61 participating countries regarding literacy ability (Lilik et al., 2020). Not much different from the data recorded in the Program for International Student Assessment (PISA). Indonesia ranks 74th out of 80 countries with low literacy rates worldwide. Meanwhile, different from the two data. According to Azmi et al. (2021:10), based on the research results obtained by $63.2 \%$ of respondents admitted that they like to read, while the rest do not. The research results can be caused by differences in the number of respondents and the duration of time, which is most likely happening here. The data may also show different results. Nevertheless, the community should not underestimate the low level of interest in reading and build better literacy for Indonesia.

Besides, digital ethics in literacy is also significant to pay attention to. It is a challenge one of the challenges for the community. Because the understanding of ethics is insufficient or tends to be lacking, it can result in the emergence of social media crime, more commonly known as cybercrime. Miftakhur (2020: 404) states that several crimes often occur on the Internet, including illegal content. Someone enters data about things that are not true and disrupts public order on the Internet or a hoax. Especially during this pandemic, crime in illegal content is widespread. Based on a report by the Law Enforcement Task Force (Satgas Gakkum), they have taken down 2400 accounts on various social media and named 107 suspects who produced and spread hoaxes related to COVID-19 on May 20, 2020 (Gatot, 2020: 307). Also, on April 27, 2020, the Ministry of Communication and Information noted that at least 600 hoaxes were spread related to the Covid-19 pandemic with various issues. It proves that the level of understanding of digital ethics in society is still low. The following is the response of one respondent regarding the importance of digital literacy skills.

I think digital literacy in the current era is critical because it will be easier for us to access information with our skills in using technology. Also, with the knowledge, we can distinguish between valid and hoax information.

Based on the respondent's statement above, it can be concluded that digital ethics in literacy in the pandemic era is critical to improving. The existence of the internet is the main factor for someone to spread information quickly, followed by the existence of social media such as Facebook, Twitter, Instagram, and Path. The media can be a new vehicle for someone to express an opinion freely to the public about anything (Anggi et al., 2018: 143). If this freedom is not balanced with knowledge related to digital literacy, it can lead someone to misleading information. According to Endang Fatmawati (2020: 96) also stated that it is crucial to balance the freedom of information: "...Along with the efforts of millennials to increase digital literacy competence, in its implementation. It must be balanced with normative knowledge related to legal rules and regulations..."

Return to the survey results and look at people who judge digital literacy as very important, necessary, and quite important. The most significant number is in critical digital literacy based on the level. It means that most people often apply digital literacy. Apart from the challenges related to digital literacy, not a few people admit that they often experience problems with their internet network. Especially for students and students often these obstacles hinder digital literacy activities. In addition to the internet network, lack of access, paid websites, English reading, and server failures are also obstacles often experienced. 
Given how crucial digital literacy is, the public should better understand the aspects of digital literacy. The government is also expected to participate in efforts to increase the understanding of digital literacy. In addition, it is also crucial for the public to know the benefits and roles of digital literacy as described in the previous point. So that technological advances are not in vain and can be applied as well as possible, especially during the current pandemic.

\section{Conclusion}

Advances in technology have made digital literacy one of the new media in accessing all the information needed. Until now, digital literacy has been at the forefront of providing many benefits, especially in information and communication. In a pandemic situation like this, digital literacy is needed in almost all aspects of life.

Based on the axiological value scheme, digital literacy has many strong values. Evidenced by the proper understanding of digital literacy will help the community in warding off hoax or invalid news and the urgent need for skills during the current pandemic. However, the literacy rate in Indonesia itself is still relatively low because several things are still obstacles. It is one of the main factors that hinder the ability of the Indonesian people in digital literacy.

Therefore, it is crucial to increase education about digital literacy to increase the Indonesian people's understanding of digital literacy. Of course, the community and the government must work together to create better digital literacy in Indonesia. With the realization of good digital literacy of the Indonesian people, Indonesia's vision will also be achieved in the 2045 golden generation.

\section{References}

Akrim, A. (2020). Etika Dalam Pengembangan Ilmu Pengetahuan Dan Teknologi. Kumpulan Makalah, Jurnal Dosen.

Al Hafidha, R. (2020). Literasi Digital Dalam Menghadapi Informasi Pandemi Covid-19 Pada Mahasiswa Ilmu Informasi Dan Perpustakaan Universitas Airlangga Surabaya (Doctoral dissertation, UNIVERSITAS AIRLANGGA).

Alvis, Y. (2020). Ketimpangan Kesempatan Pendidikan dan Literasi Digital di Indonesia (Doctoral dissertation, UNIVERSITAS AIRLANGGA).

Anggraeni, H., 2019. Penguatan Blended Learning Berbasis Literasi Digital dalam Menghadapi Era Revolusi Industri 4.0. Al-Idarah: Jurnal Kependidikan Islam, 9(2), pp.190- 203.

Anim, A., Armanto, D., \& Sari, N. (2021). PERSPEKTIF KAJIAN AKSIOLOGI PADA PEMBELAJARAN DARING DI ERA PANDEMIC. JOURNAL OF SCIENCE AND SOCIAL RESEARCH, 4(3), 276-282.

Ayu, W. (2020). Kejahatan Siber Dalam Perspektif Era Pandemi Covid-19. URL:

Https://Www.Ui.Ac.Id/Kejahatan-Siber-Dalam-Perspektif-Era-Pandemi-Covid-19/. Accessed November 14, 2021.

Bastian, O. A., Rahmat, H. K., Basri, A. S. H., Rajab, D. D. A., \& Nurjannah, N. (2021). Urgensi Literasi Digital dalam Menangkal Radikalisme pada Generasi Millenial di Era Revolusi Industri 4.0. Jurnal Dinamika Sosial Budaya, 23(1), 126-133.

Buwono, S., \& Dewantara, J. A. (2020). Hubungan Media Internet, Membaca, Dan Menulis 
Dalam Literasi Digital Mahasiswa. Jurnal Basicedu, 4(4), 1186-1193.

Cahyani, E. D. (2019). Analisis Penerimaan Aplikasi Ruang Guru Sebagai Media Pemenuhan Informasi Akademik Siswa Sma Di Kota Surabaya Ditinjau Dari Model Utaut2 (Doctoral dissertation, Universitas Airlangga).

Dinata, K. B. (2021). Analisis Kemampuan Literasi Digital Mahasiswa. Edukasi: Jurnal Pendidikan, 19(1), 105-119.

Dinata, K. B. (2021). Literasi Digital Dalam Pembelajaran Daring. Eksponen, 11(1), 20-27.

Fatmawati, E. (2020). Kebebasan Informasi Kalangan Milenial Dalam Bermedia Sosial. Jpua: Jurnal Perpustakaan Universitas Airlangga: Media Informasi Dan Komunikasi Kepustakawanan, 10(2), 94-103.

Fitriyani, F., \& Mukhlis, S. (2021). Urgensi Penggunaan Digital Literasi Dalam Pelaksanaan Pendidikan Dimasa Pandemi: Systematic Literature Review. Dikoda: Jurnal Pendidikan Sekolah Dasar, 1(01), 13-20.

Fitriyani, Y., \& Aziz, I. (2019). Literasi Era Revolusi Industri 4.0. Prosiding SENASBASA, 3(1), $100-104$.

Ginting, E. S. (2021). Penguatan Literasi Di Era Digital. In Prosiding Seminar Nasional Pembelajaran Bahasa Dan Sastra Indonesia (Semnas PBSI)-3 (Pp. 35-38). Fbs Unimed Press.

Habibi M.R., \& Isnatul L. (2020). Kejahatan Teknologi Informasi (Cyber Crime) Dan Penanggulangannya Dalam Sistem Hukum Indonesia. Al-Qānūn: Jurnal Pemikiran Dan Pembaharuan Hukum Islam, 23(2), 411-412

Hadayani, D. O., Delinah, \& Nurlina. (2020). Membangun Karakter Siswa Melalui Literasi Digital Dalam Menghadapi Pendidikan Abad 21 (Revolusi Industri 4.0). Prosiding Seminar Nasional Pendidikan Program Pascasarjana Universitas PGRI Palembang, 21, 999-1015.

Harahap, E., Istianingsih, N., Latief, M. (2020). Perkembangan Filsafat Ilmu dalam Perspektif Teknologi Digital. Jurnal Administrasi Sosial dan Humaniora (JASIORA), 2(1), 9-23.

Harisanty, D., Srirahayu, D. P., Anna, N. E. V., Mannan, E. F., Anugrah, E. P., Nurpratama, M. R., \& Dina, N. Z. (2021). SOCIALIZATION OF DIGITAL LITERACY EDUCATION TO ANTICIPATE HOAX NEWS. Darmabakti Cendekia: Journal of Community Service and Engagements, 3(1), 33-37.

Harjono, H. S. (2018). Literasi Digital: Prospek Dan Implikasinya Dalam Pembelajaran Bahasa. Pena: Jurnal Pendidikan Bahasa Dan Sastra, 8(1), 1-7.

Hasanah, U. (2020). Aksiologi Ilmu Dalam Tradisi Islam Dan Barat.Hasanah, U. (2020). Aksiologi Ilmu Dalam Tradisi Islam Dan Barat.

Hasil Survei Indeks Literasi Digital Nasional 2020, Akses Internet Makin Terjangkau (2020). kominfo.go.id. accessed December 19, 2021. From https://kominfo.go.id/content/detail/30928/siaran-pers-no-149hmkominfo112020-tentang-hasilsurvei-indeks-literasi-digital-nasional-2020-akses-internet-makin-terjangkau/0/siaran pers 
Herpendi, H., \& Hafizd, K. A. (2021). Pentingnya Memiliki Digital Skills Di Masa Pandemi COVID-19. Jurnal WIDYA LAKSMI (Jurnal Pengabdian Kepada Masyarakat), 1(2), 83-90.

Hidaya, N., Qalby, N., \& Alaydrus, S.S. (2019). Pengaruh Media Sosial Terhadap Penyebaran Hoax Oleh Digital Native. Universitas Muslim Indonesia

Irhandayaningsih, A. (2020). Pengukuran Literasi Digital Pada Peserta Pembelajaran Daring di Masa Pandemi COVID-19. Anuva, 4(2), 231-240.

Izni, I. (2019). Kemampuan Literasi Digital Dalam Menilai Berita Hoax Di Media Daring Di Kalangan Mahasiswa Aktivis Universitas Airlangga Surabaya (Doctoral dissertation, Universitas Airlangga).

Jaya, I. K. N. A. (2020). Filsafat Ilmu dalam Iptek.

Jelahut, F., Utang, H., Jelahut, Y., Jehamat, L. (2021). Menalar Skeptis Adopsi Artificial Intelegence (AI) di Indonesia: 'Sebuah Tinjauan Filsafat Ilmu Komunikasi'. Jurnal Filsafat Indonesia, 4(2), 172-178.

Karlina, E., Suratriadi, P., Mutiah, T., \& Kurniawan, F. (2021). WHATSAPP SEBAGAI MEDIA LITERASI DIGITAL SEBAGAI MEDIA UNTUK PEMBELAJARAN JARAK JAUH (PJJ) DIMASA PANDEMI. Global Komunika: Jurnal Ilmu Sosial dan Ilmu Politik, 4(1), 41-50.

KHOLID, K. (2020). PENTINGNYA LITERASI DIGITAL BAGI GURU PADA LEMBAGA PENDIDIKAN TINGKAT DASAR DAN IMPLIKASINYA TERHADAP PENYELENGGARAAN KEGIATAN BELAJAR MENGAJAR. Jurnal Horizon Pedagogia, 1(1).

Kurniawati, Y.R. (2020). Pertanggungjawaban Pidana Atas Berita Bohong (Hoax) di Media Sosial. Dinamika: Jurnal Ilmiah Ilmu Hukum, 26(4), 422-437

Latip, A. (2020). Peran literasi teknologi informasi dan komunikasi pada pembelajaran jarak jauh di masa pandemi Covid-19. EduTeach: Jurnal Edukasi dan Teknologi Pembelajaran, 1(2), 108-116.

Limilia, P., \& Aristi, N. (2019). Literasi Media dan Digital di Indonesia: Sebuah Tinjauan Sistematis. Jurnal KOMUNIKATIF Vol, 8(2), 205.

Muannas, M., \& Mansyur, M. (2020). Model Literasi Digital untuk Melawan Ujaran Kebencian di Media Sosial (Digital Literacy Model to Counter Hate Speech on Social Media). JURNAL IPTEKKOM (Jurnal Ilmu Pengetahuan \& Teknologi Informasi), 22(2), 125-142.

Murti, K. K. (2020). Pergeseran Perilaku Penemuan Informasi Di Kalangan Mahasiswa Sebagai Generasi Digital Natives (Doctoral dissertation, UNIVERSITAS AIRLANGGA).

Muslimin, M., \& Idul, R. (2020). PENGARUH BUDAYA LITERASI DIGITAL TERHADAP PEMBENTUKAN SIKAP DAN KARAKTER MASYARAKAT DALAM PEMBATASAN SOSIAL AKIBAT PANDEMI COVID-19. Jurnal Bahasa, Sastra, dan Budaya, 10(3), 21-36.

Olivia, L. (2021). Pelanggaran Hak Kekayaan Intelektual Dinilai Masih Marak. URL: Https:/Www.Beritasatu.Com/Ekonomi/767127/Pelanggaran-Hak-Kekayaan-Intelektual- DinilaiMasih-Marak. Accessed, November 13, 2021. 
Pramono, G.E. (2020). Kejahatan Penyebaran Hoaks Saat Pandemi Covid-19. Jurnal Ilmu Hukum Fakultas Hukum Universitas Riau, 9(2), 304-317

Pratama, W. A., Hartini, S., \& Misbah. (2019). Analisis Literasi Digital Siswa Melalui Penerapan E-Learning Berbasis Schoology. Jurnal Inovasi Dan Pembelajaran Fisika, 06(1), 9-13.

Priambodo, A. W. (2020). Literasi Digital Warga Surabaya Saat Pandemi Covid-19 (Studi Deskriptif Mengenai Tingkat Kompetensi Literasi Digital Warga Surabaya saat Pandemi Covid-19) (Doctoral dissertation, UNIVERSITAS AIRLANGGA).

Rahardaya, A. K. (2021). Studi Literatur Penggunaan Media Sosial Tiktok Sebagai Sarana Literasi Digital Pada Masa Pandemi Covid-19. Jurnal Teknologi Dan Sistem Informasi Bisnis-Jteksis, 3(2), 308-319.

Rasunnah, A. N. M. (2021). Cancel Culture sebagai Pengendalian Sosial terhadap Influencer Penyebar Berita Hoaks mengenai Pandemi Covid-19 (Doctoral dissertation, UNIVERSITAS AIRLANGGA).

Rianto, P. (2019). Literasi Digital Dan Etika Media Di Era Post-Truth. Jurnal Ilmu Komunikasi, $12(8), 1-8$

Rizky, A.A., Ala, \& Kayla. (2021). Pengaruh Kurangnya Literasi Serta Kemampuan Dalam Berpikir Kritis Yang Masih Rendah Dalam Pendidikan Di Indonesia. Current Research In Education: Conference Series Journal, 1(1), 10-11

Rochadiani, T. H., Santoso, H., \& Dazki, E. (2020). Peningkatan Literasi Digital Pada Masa Pandemi Covid-19. Jurnal Pengabdian Masyarakat, 1(1), 11-21.

Rosnawati, R., Syukri, A.S.A., Badarussyamsi, B. and Rizki, A.F.R.A.F., 2021. Aksiologi Ilmu Pengetahuan dan Manfaatnya Bagi Manusia. Jurnal Filsafat Indonesia, 4(2), pp.186-194.

Salsabiila, K. (2019). Fungsi Smartphone Pada Mahasiswa Penyandang Tunanetra Di Kampus B Universitas Airlangga (Doctoral dissertation, UNIVERSITAS AIRLANGGA).

Sari, N.W. (2019). Kejahatan Cyber Dalam Perkembangan Teknologi Informasi Berbasis Komputer. Jurnal Surya Kencana Dua: Dinamika Masalah Hukum dan Keadilan, 5(2), 577-591

Sari, S. (2019). Literasi Media pada Generasi Milenial di Era Digital. Professional: Jurnal Komunikasi dan Administrasi Publik, 6(2), 30-42.

Sari, S. S. (2019). Kemampuan Literasi Digital Kalangan Siswa SMP dan SMA di Daerah Pedesaan Kabupaten Blitar (Doctoral dissertation, UNIVERSITAS AIRLANGGA).

Setyaningsih, R., Abdullah, A., Prihantoro, E., \& Hustinawaty, H. (2019). Model penguatan literasi digital melalui pemanfaatan e-learning. Jurnal Aspikom, 3(6), 1200-1214.

Sistarina, A. (2020). Implementasi Literasi Informasi Sebagai Upaya Perpustakaan Universitas Airlangga Mendukung Tri Dharma Perguruan Tinggi. JPUA: Jurnal Perpustakaan Universitas Airlangga: Media Informasi dan Komunikasi Kepustakawanan, 10(2), 104-115.

Sitorus, J.P. (2019). Literasi Digital: Kontribusi Dan Tantangan Dalam Keterampilan Menulis. Jurnal Bahasa, Sastra, Dan Pembelajarannya, 2(2), 75-85 
Sujana, A., \& Rachmatin, D. (2019). Literasi digital abad 21 bagi mahasiswa PGSD: apa, mengapa, dan bagaimana. In Current Research in Education: Conference Series Journal (Vol. 1, No. 1, pp. 003-013).

Sumiati, E., \& Wijonarko, W. (2020). Manfaat Literasi Digital Bagi Masyarakat Dan Sektor Pendidikan Pada Saat Pandemi Covid-19. Buletin Perpustakaan, 65-80.

Surbakti, J., Putra, D., \& Defkasari, I. (2021). Etika Komunikasi Digital: Cara Pandang Filsafat Islam Terhadap Realitas Masyarakat Muslim Kontemporer. Sulthan Thaha Journal of Social And Political Studies, 1(01).

Syafitri, E., Armanto, D., \& Rahmadani, E. (2021). AKSIOLOGI KEMAMPUAN BERPIKIR KRITIS (Kajian Tentang Manfaat dari Kemampuan Berpikir Kritis). JOURNAL OF SCIENCE AND SOCIAL RESEARCH, 4(3), 320-325

Syarifah, I. L., Raharani, F. A., Izzah, N., Mukarromah, S., Yulianti, Y., Geografi, P. P., Sosial, F. I., Semarang, U. N., Matematika, P. P., Semarang, U. N., Semarang, U. N., Biologi, P., Semarang, U. N., \& Artikel, I. (2021). Pentingnya Literasi Digital di Era Pandemi. 1(2), 162-168.

Tahmidaten, L., \& Wawan K. (2020). Permasalahan Budaya Membaca Di Indonesia (Studi Pustaka Tentang Problematika \& Solusinya). Scholaria: Jurnal Pendidikan Dan Kebudayaan, 10(1), 22-23.

Topan, M. (2020). PRAGMATISME DALAM PENDIDIKAN DI INDONESIA: KRITIK DAN RELEVANSINYA. Al-Idrak: Jurnal Pendidikan Islam dan Budaya, 1(1), 16-26.

Triandi, B. (2019). Keamanan Informasi secara Aksiologi Dalam Menghadapi Era Revolusi Industri 4.0. Jurnal Riset Komputer (JURIKOM), 6(5), 477-483.

Yuniar, A. D., Fibrianto, A. S., Prabawangi, R. P., \& Ananda, K. S. (2019). MENCIPTAKAN PEREMPUAN CERDAS BERINTERNET MELALUI PENANAMAN LITERASI DIGITAL KOMUNITAS 'RUANG BERKARYA PEREMPUAN'. Jurnal Praksis dan Dedikasi Sosial $(J P D S), 2(2), 47-53$.

Yunus, M. (2020). ISU AKSIOLOGI DALAM FILSAFAT ILMU KOMUNIKASI. Jurnal Khabar: Komunikasi Dan Penyiaran Islam, 2(1), 43-56. 